\title{
Increased thermal stability of phycocyanin extracted from Spirulina platensis by cysteine addition during enzyme extraction
}

\author{
Chi-Woo LEE ${ }^{1,2}$, Gi Yeon BAE ${ }^{1}$, Song-Hwan BAE³, Hyung Joo SUH ${ }^{1,4}$, Kyungae JO ${ }^{1 \star}$
}

\begin{abstract}
Phycocyanin, a natural pigment extracted from spirulina (Spirulina platensis), is used in foods, but its use is limited due to its relatively heat labile nature. Thus, here, we aimed to investigate the effect of cysteine addition on increasing the thermal stability of phycocyanin extracted from spirulina using Collupulin. Our results showed that $0.5 \%$ cysteine was the most effective in extracting phycocyanin. Furthermore, $95^{\circ} \mathrm{C}$ heat treatment increased the stability of phycocyanin extracted with Collupulin and cysteine. The thermal kinetic model of the phycocyanin extracted with Collupulin and cysteine was confirmed to follow the second order. The activation energy of phycocyanin extracted with Collupulin and cysteine, calculated using the reaction constant $(k)$ obtained from the secondary thermal kinetic model, was $65.3 \mathrm{~kJ}$. Collectively, the addition of $0.5 \%$ cysteine increased the thermal stability of phycocyanin extracted with Collupulin, and this phycocyanin could be used in foods that undergo a heating process.
\end{abstract}

Keywords: phycocyanin; thermal stability; Collupulin; cysteine.

Practical Application: Consider the thermal stability and functional quality of phycocyanin extracted by enzymes with the addition of cysteine.

\section{Introduction}

Spirulina (Spirulina platensis) is a cyanobacterium (blue-green algae) that is widely grown in alkaline brine lakes (Nege et al., 2020). Spirulina is nontoxic, contains polysaccharides, vitamins, minerals, unsaturated fatty acids, carotenoids, and phycobiliproteins, and is used as a food supplement (Lafarga et al., 2020; Sánchez et al., 2003). In addition to fibers and pigments, the biomass of spirulina consists of 55-70\% protein, 3-9\% fat, and $15-30 \%$ carbohydrates (Kay \& Barton, 1991). Spirulina markedly differs from other microalgae because it contains large amounts of protein pigments called phycobiliproteins (Glazer, 1985), which are phycobilisomes attached to the thylakoid membranes of chloroplasts and auxiliary photosynthetic pigments that aggregate in cells (Arad \& Yaron, 1992). Phycobiliprotein consists of three main components: phycoerythrin, phycocyanin, and allophycocyanin (Sonani et al., 2016). Among them, phycocyanin is a blue-colored natural pigment with various physiological activities (antioxidant, antibacterial, and anticancer activity); thus, it is a protein pigment that can also be used in the food industry as a bioactive substance (Kumar et al., 2014; Liu et al., 2016).

Phycocyanin extracted from spirulina is a water-soluble proteinpigment complex. To maintain the stability of the phycocyanin molecule, proper $\mathrm{pH}$ control and ionic strength is required during extraction, separation, and purification. The aggregation state of the protein is dependent on the changes in conditions such as light, temperature, $\mathrm{pH}$, and protein concentration, which further affects the degradation of phycocyanin (Berns \& MacColl,
1989; Jespersen et al., 2005). Heat causes phycocyanin precipitation and its discoloration from blue thereby limiting its use. Although many studies have attempted to increase the thermal stability of phycocyanin, its use as a food additive is not recommended owing to the use of preservatives such as sodium azide (Mishra et al., 2008). In addition, low levels of sugar or polyhydric alcohols are used to increase the stability of pigment proteins (Petersen et al., 2004). Several studies have reported that the rearrangement of protein structures can improve the stability of pigment proteins (Fukui et al., 2004). In particular, cysteine (Cys) is known to inhibit protein denaturation by preventing the oxidation of thiol groups. The disulfide bonds of this cysteine play an important role in the folding and stability of some proteins by stabilizing the folded form (Fass, 2012). Recently, studies have been conducted to maintain pigment stability for 45 days at room temperature $\left(25^{\circ} \mathrm{C}\right)$ by adding citric acid (Mishra et al., 2008; Mishra et al., 2008), but no clear alternatives have been proposed to secure stability during the heat treatment of phycocyanin. In particular, there is no method for ensuring pigment stability during the heat treatment process of foods in which phycocyanin is used.

In previous studies, Collupulin has been shown to improve the extraction efficiency of phycocyanin from spirulina, and the extraction conditions have also been reported. In this study, we aimed to examine the effect of Cys addition on increasing the thermal stability of phycocyanin extracted from spirulina using Collupulin. 


\section{Materials and methods}

\subsection{Materials}

Earthrise ${ }^{\circledR}$ Natural Spirulina powder (Earthrise Nutritionals LLC, Calipatria, CA, USA) was used for phycocyanin pigment extraction. Collupulin (EC 3.4.22.25.4, DSM Food specialties, Delft, The Netherlands) from Papaya (Carica papaya) was used as the hydrolase. The enzyme reaction conditions were $\mathrm{pH} 5.0$ 7.5 , temperature $55-70^{\circ} \mathrm{C}$, and the enzyme activity $10^{6} \mathrm{PU} / \mathrm{g}$.

\subsection{Phycocyanin extract from spirulina}

Water and enzyme extracts from spirulina were prepared to evaluate the thermal stability of phycocyanin. The water extract was added to $60 \mathrm{~mL}$ of citrate buffer ( $50 \mathrm{mM}, \mathrm{pH} 5.0)$ and spirulina powder $(2,5$, and $10 \%, \mathrm{w} / \mathrm{v})$, extracted at $45^{\circ} \mathrm{C}$ for $12 \mathrm{~h}$, and centrifuged $\left(2500 \mathrm{xg}, 20 \mathrm{~min}, 4^{\circ} \mathrm{C}\right)$. The resulting supernatant (phycocyanin) was used for further analyses. Enzyme extraction was performed according to a previously reported method (Bae et al., 2020). After suspension at a concentration of 5\% $(\mathrm{w} / \mathrm{v})$ spirulina in $0.05 \mathrm{M}$ citrate buffer $(\mathrm{pH} 5.0), 3 \%(\mathrm{w} / \mathrm{w})$ of the enzyme amount based on the substrate was added. The reaction was performed at $45^{\circ} \mathrm{C}$ for $12 \mathrm{~h}$. Then, the enzyme was inactivated by heating the mixture at $95^{\circ} \mathrm{C}$ for $10 \mathrm{~min}$, and the supernatant was recovered by centrifugation ( $9500 \mathrm{x} g, 5 \mathrm{~min}, 4^{\circ} \mathrm{C}$ ) and used as a phycocyanin enzyme extract. Extracts were lyophilized for further experiments.

\subsection{Analysis of C-phycocyanin and allophycocyanin}

The extraction yield was calculated using the weight ratio of the applied raw spirulina powder and the freeze-dried extract. For phycocyanin and allophycocyanin, the absorbance of the supernatant obtained after enzymatic extraction was measured at $620 \mathrm{~nm}$ and $652 \mathrm{~nm}$, respectively, and calculated using the following Formula 1 and 2 (Bennett \& Bogorad, 1973).

$C-$ phycocyanin $(\mathrm{mg} / \mathrm{mL})=[$ A620-0.474 $($ A652) $] / 5.34$

Allophycocyanin $(\mathrm{mg} / \mathrm{mL})=[$ A652-0.208 $($ A620) $] / 5.09$

A620: absorbance at $620 \mathrm{~nm}$, A652: absorbance at $652 \mathrm{~nm}$

\subsection{Stability of phycocyanin pigment}

To measure the thermal stability of the phycocyanin solution according to this extraction method and following the addition of Cys, the absorbance was measured at $620 \mathrm{~nm}$ before and after the heat treatment at 70,80 , and $90{ }^{\circ} \mathrm{C}$ for $30 \mathrm{~min}$ at $\mathrm{pH} 5.0$. The thermal stability of phycocyanin extracted with citrate buffer alone, $0.5 \%(\mathrm{w} / \mathrm{v})$ Cys and citrate buffer, 3\% (w/w) Collupulin and $0.5 \%$ Cys, and addition of $0.5 \%$ Cys after the extraction with Collupulin was evaluated. The stability of the pigment was expressed as the relative residual amount of phycocyanin $\left(C_{R}, \%\right)$ before and after treatment. $C_{R}(\%)=C / C_{0} \times 100$; the relative concentration of phycocyanin $\left(C_{R}, \%\right)$ is the remaining concentration of phycocyanin as a percentage of the initial concentration $\left(\mathrm{C}_{0}\right)$.

\subsection{Statistical analysis}

The results of the experiments are expressed as the mean \pm standard deviation (SD) of three replicates. Statistical analyses were performed using the SPSS 17 version for Windows (SPSS Inc., Chicago, IL, USA) with the significance level set at $p<0.05$ ). Data were analyzed using one-way analysis of variance (ANOVA) and significance was verified by Duncan's multiple range test.

\section{Results and discussion}

\subsection{Phycocyanin extraction by Collupulin from spirulina}

Phycocyanin is a water-soluble natural pigment widely used as a coloring additive in food, cosmetics, fluorescent reagents, probes, and tracers in clinical diagnostic instruments. Various techniques have been used to extract phycocyanin from spirulina biomass. The cell membrane of spirulina is similar to that of gram-negative bacteria; it is composed of two lipid membrane layers (cellular and cytoplasmic), separated by a murein layer (Palinska \& Krumbein, 2000). Murein is a rigid macromolecular structure formed from peptidoglycans and lipopolysaccharides (Verdasco-Martín et al., 2019). Decomposing such cell membranes require physical methods, enzymes, and chemical methods. For example, Alcalase ${ }^{\circledR}$ and Flavourzyme ${ }^{\circledR}$ proteases degrade membrane proteins, lipoproteins, and peptidoglycans, while Ultraflo $^{\circledR}$ and Vinoflow ${ }^{\circledR}$, which are endo- and exo-glucanases, respectively, degrade sugar polymers. The active ingredient obtained from spirulina varies depending on the enzyme used for digestion. According to our previous study, Collupulin treatment was more effective in recovering phycocyanin from spirulina than Flavourzyme or Alcalase treatment (Bae et al., 2020).

According to previous studies (Bae et al., 2020), as the amount of Collupulin increases, the contents of C-phycocyanin and allophycocyanin increase. The contents of C-phycocyanin and allophycocyanin are the highest compared to the control (without Collupulin added) when 3.0\% Collupulin is added. For the industrial production of phycocyanin, the higher the amount of spirulina, the substrate, is advantageous. Therefore, the amount of phycocyanin extracted from a known amount of spirulina was measured (Figure 1). The amount of phycocyanin extracted increased until the addition of $5 \%$ spirulina, but it decreased with the addition of $10 \%$ spirulina. Additionally, the extraction yield decreased as the amount of spirulina added increased. These results suggest that C-phycocyanin and allophycocyanin pigments should be extracted with Collupulin from 2 to $5 \%$ spirulina.

\subsection{Thermal stability by adding Cys to phycocyanin obtained by different extraction methods}

When phycocyanin was extracted with Collupulin, Cys was added to increase the stability of the phycocyanin pigment (Figure 2). As the amount of Cys added increased to $0.5 \%$, the amount of C-phycocyanin and allophycocyanin pigments extracted gradually increased. However, when more than $0.5 \%$ Cys was added, the amount of pigments extracted decreased. Furthermore, the amount of phycocyanin obtained by extraction with Collupulin and $0.5 \%$ Cys was $52.6 \%$ higher than the amount of phycocyanin extracted 

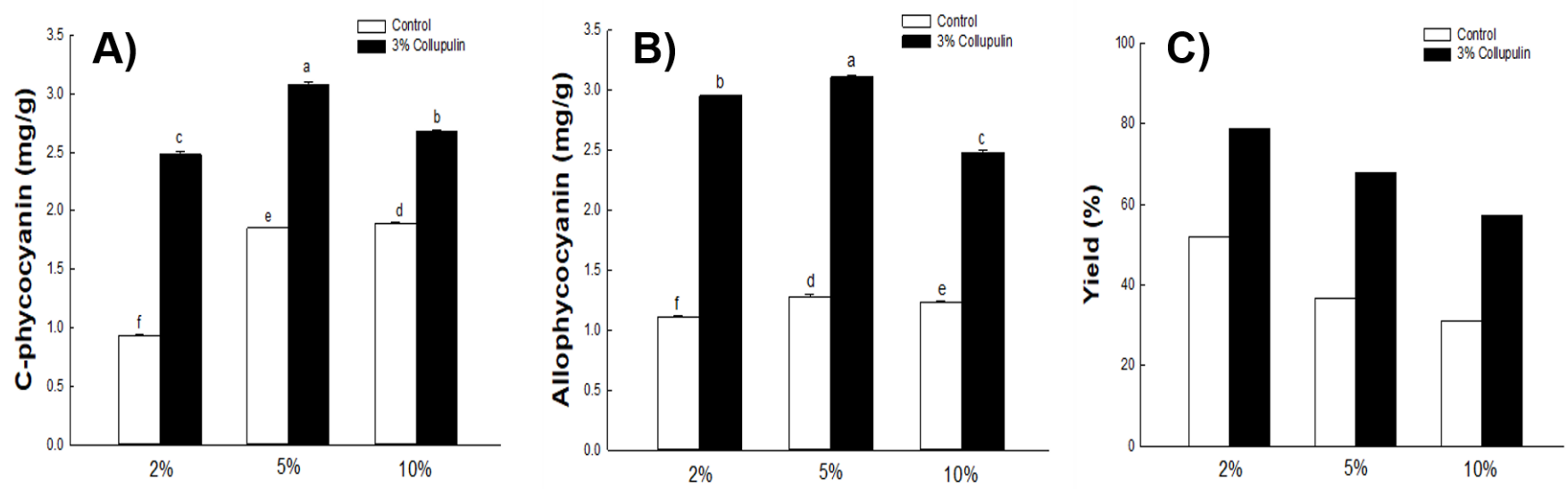

Figure 1. C-Phycocyanin and allophycocyanin production by extraction with Collupulin from different concentrations of spirulina $(2,5$, and $10 \%, \mathrm{w} / \mathrm{v}$ ). The reaction was performed for $12 \mathrm{~h}$ at $40{ }^{\circ} \mathrm{C}$ and $\mathrm{pH} 5.0$ by adding $3 \%(\mathrm{w} / \mathrm{w}$ ) of Collupulin. (A) C-phycocyanin; (B) allophycocyanin; (C) yield. Values are presented as the mean \pm standard deviation (SD) for each group. Different letters indicate significant differences $(\mathrm{p}<0.05$ ) among samples by one-way ANOVA followed by post-hoc Duncan's test.

with citrate buffer alone. Cys addition appears to increase the thermal stability of the pigment during the extraction process rather than increase the amount of phycocyanin extracted.

To determine whether the increase in the amount of phycocyanin extraction was caused by the increase in thermal stability, thermal stability of phycocyanin extracts was measured after adding Cys to phycocyanin and using different extraction methods: extraction with citrate buffer alone, Cys and citrate buffer, Collupulin and Cys, and Cys addition after extraction with Collupulin (Figure 3). Regardless of the extraction method or the timing of Cys addition, the addition of Cys increased the thermal stability of phycocyanin. As the concentration of Cys increased, the thermal stability of phycocyanin tended to increase. In particular, the addition of $0.2 \%$ and $0.5 \%$ Cys significantly increased the thermal stability of phycocyanin compared to the group with no or $0.1 \%$ Cys addition $(p<0.05)$. When the extraction involved both Cys and Collupulin, phycocyanin thermal stability was higher than when Cys was added to the extract after extraction with Collupulin. Phycocyanin is unstable to heat and cannot be used in foods that require high-temperature processes such as cooking or sterilization. The thermal stability of phycocyanin is only slightly increased by adding a preservative or low concentration of sugar (Hadiyanto et al., 2018). Compounds, such as dithiothreitol and sodium azide, are used to increase the stability of phycobiliproteins, but their use is limited owing to toxicity (Mishra et al., 2010). In general, these compounds are known to prevent the oxidation of thiol groups. Cys also seems to inhibit the protein denaturation of phycobiliproteins by preventing the oxidation of thiol groups. Phycocyanin is known to have Cys residues, and the formation of covalent disulfide bonds between them causes protein stabilization (Fass, 2012). Cys addition appears to contribute to the protection and stabilization of the thiol groups involved in this covalent disulfide bond formation, suggesting why it is more efficient to add it during extraction with Collupulin (Figure 3).
Phycobiliproteins containing phycocyanin act as an auxiliary light-harvesting antenna complex to cyanobacteria, absorbing sunlight and efficiently transferring it to chlorophyll $\mathrm{A}$ in the reaction center. These phycobiliproteins are classified into phycoerythrin, phycocyanin, and allophycocyanin and have maximum absorption wavelengths of 540-570, 610-620, and 650-655 nm, respectively (Kannaujiya \& Sinha, 2015; SantiagoSantos et al., 2004). Spirulina extract obtained using Collupulin also contains phycocyanin with a maximum absorption wavelength of $610 \mathrm{~nm}$. Figure 4 shows the changes in absorbance and pigment (according to wavelength change) before and after heat treatment. The pigment stability of phycocyanin obtained by adding cysteine during the extraction with Collupulin was higher than that of phycocyanin extracted with either citrate buffer or Collupulin alone.

\subsection{Thermal stability of phycocyanin by adding cysteine during extraction with Collupulin from spirulina}

For thermal stability, Chaiklahan et al. (2012) reported that the effects of temperature, $\mathrm{pH}$, and preservative addition on phycocyanin solutions depend on the first-order kinetics of thermal degradation. The thermal stability of phycocyanin was measured based on the amount of Cys added during extraction with Collupulin from spirulina. The change in $C_{R}$ value, the thermal stability index of phycocyanin, after $95^{\circ} \mathrm{C}$ heat treatment for $10 \mathrm{~min}$ is shown in Figure $3 \mathrm{~A}$. The $\mathrm{C}_{\mathrm{R}}$ value of the extract obtained after extraction with Collupulin was $33.6 \%$, which was higher than that of the extract obtained after extraction with citrate buffer ( $\mathrm{pH} 5.0$ ) alone. In contrast, when extracted with Collupulin and $0.1 \%, 0.2 \%$, and $0.5 \%$ Cys, the $C_{R}$ values of the phycocyanin were $33.8 \%, 43.4 \%$, and $58.4 \%$, respectively, which were higher than those obtained after extraction with either citrate buffer or Collupulin alone. These results indicate that Cys addition during phycocyanin extraction was effective in increasing the thermal stability of the pigment. 

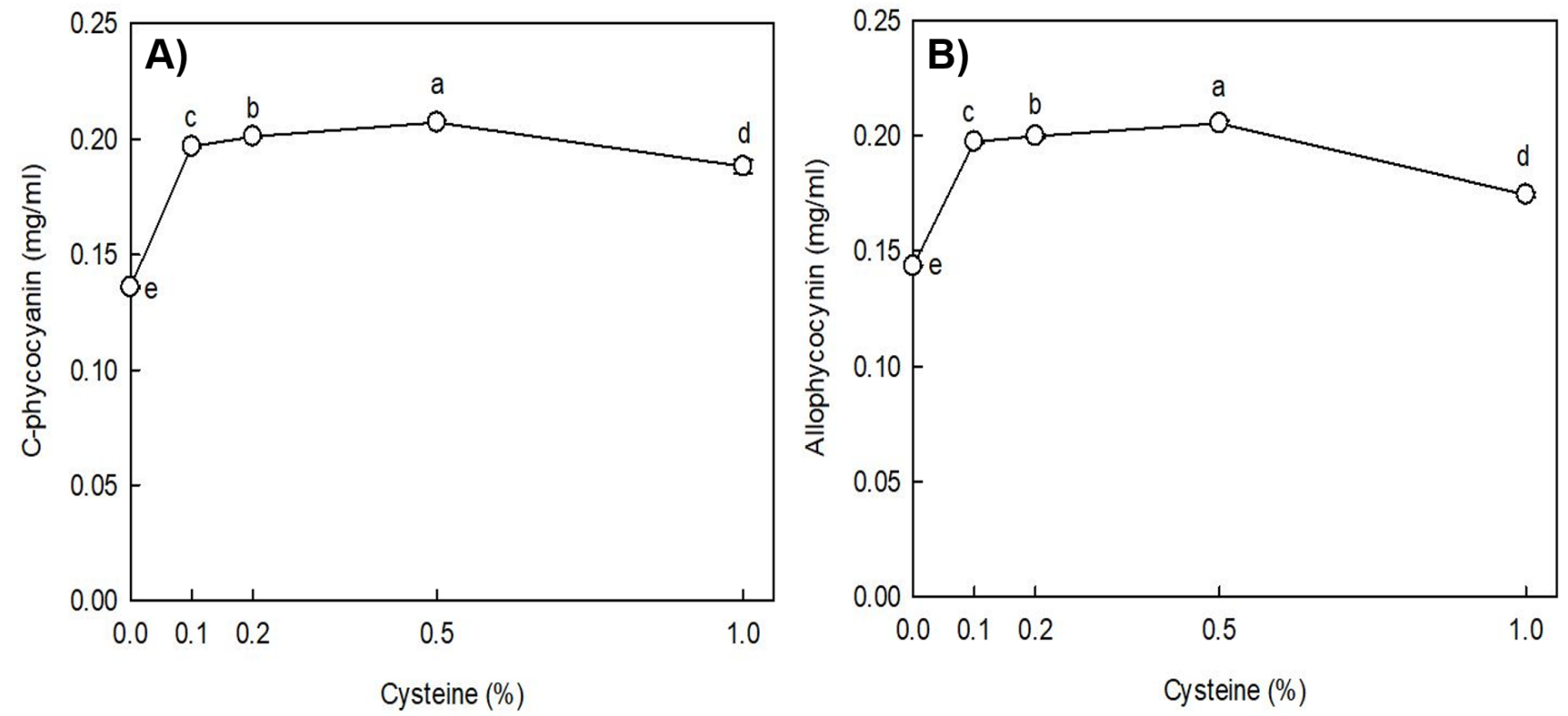

Figure 2. Effect of cysteine $(0.1,0.2,0.5,1.0 \%, \mathrm{w} / \mathrm{v})$ addition during extraction with Collupulin on phycocyanin. The reaction was performed for $12 \mathrm{~h}$ at $40{ }^{\circ} \mathrm{C}$ and $\mathrm{pH} 5.0$ by adding cysteine to spirulina $(5 \%, \mathrm{w} / \mathrm{v})$ and Collupulin (3\%,w/w). (A) C-phycocyanin; (B) allophycocyanin. Values are presented as the mean \pm standard deviation (SD) for each group. Different letters indicate significant differences $(\mathrm{p}<0.05)$ among samples by one-way ANOVA followed by post-hoc Duncan's test.
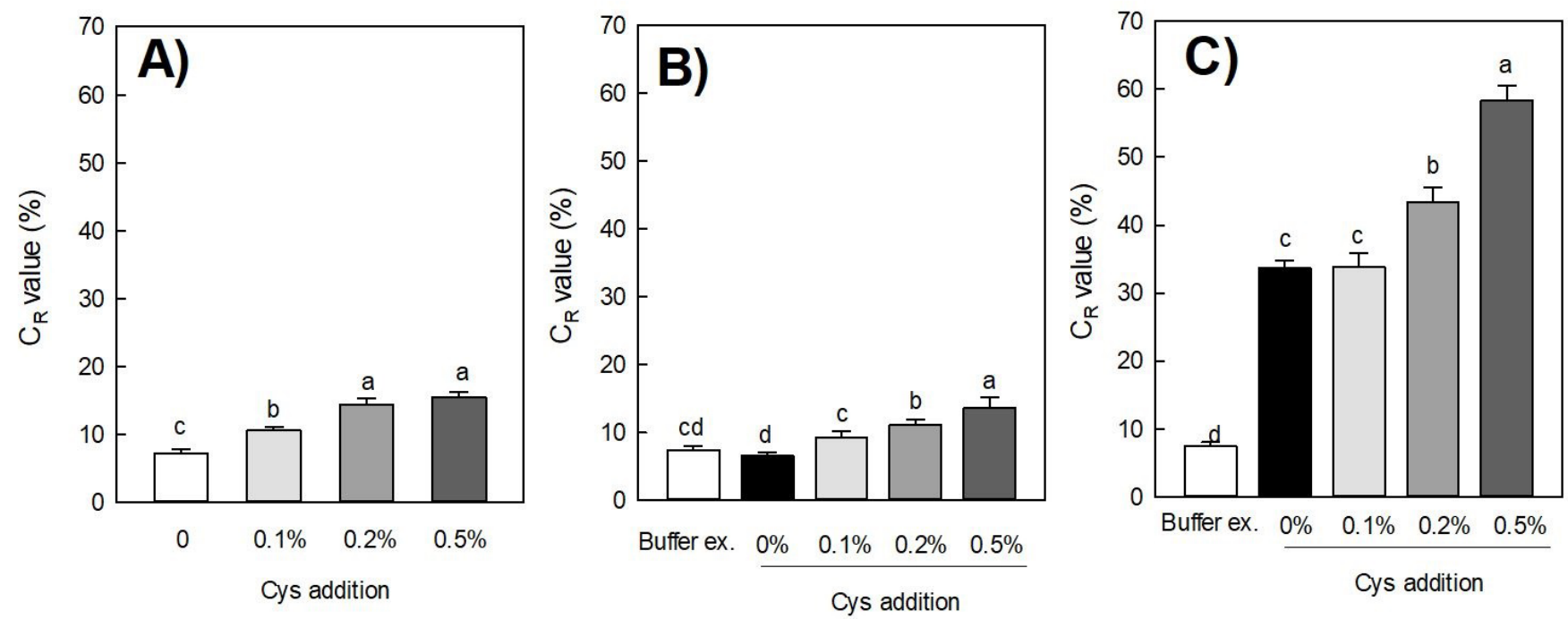

Figure 3. Thermal stability $\left(C_{R}\right.$ value) of phycocyanin from extracts obtained from spirulina using different extraction methods. (A) Citrate buffer extraction; (B) Cysteine addition after Collupulin extraction; (C) Collupulin estraction with cysteine. (A) C-phycocyanin; (B) allophycocyanin; (C) yield. Values are presented as the mean \pm standard deviation (SD) for each group. Different letters indicate significant differences $(\mathrm{p}<0.05)$ among samples by one-way ANOVA followed by post-hoc Duncan's test.

\subsection{Thermal kinetics and the effect of temperature on phycocyanin degradation}

Thermal denaturation causes changes in the chemical, physical, and biological properties of natural protein structures through repulsion and vibration (Volkin \& Middaugh, 1992). To assess the thermal denaturation of phycocyanin at different $\mathrm{pH}$ levels, we used second-, first-, and zero-order motion models (Hadiyanto et al., 2018). The kinetic models are expressed by the following Equations 1,4 and 5:

Zero order: $C_{t}-C_{0}=-k_{0} t$

First order: $\ln C_{t} / C_{0}=-k_{l} t$ 


\section{Buffer extract}

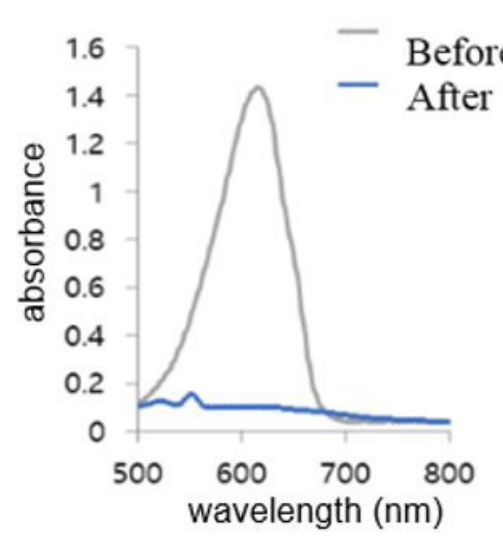

Collupulin extract

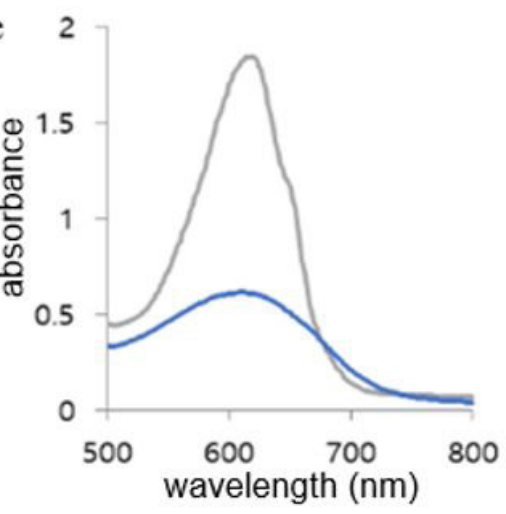

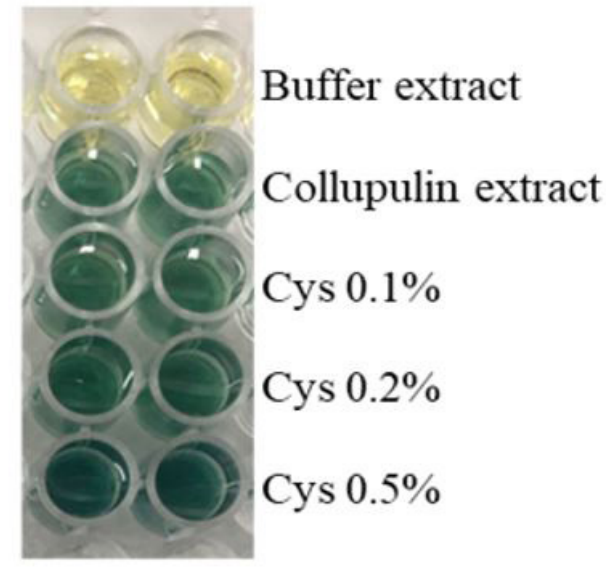

Addition of Cys during Collupulin extraction

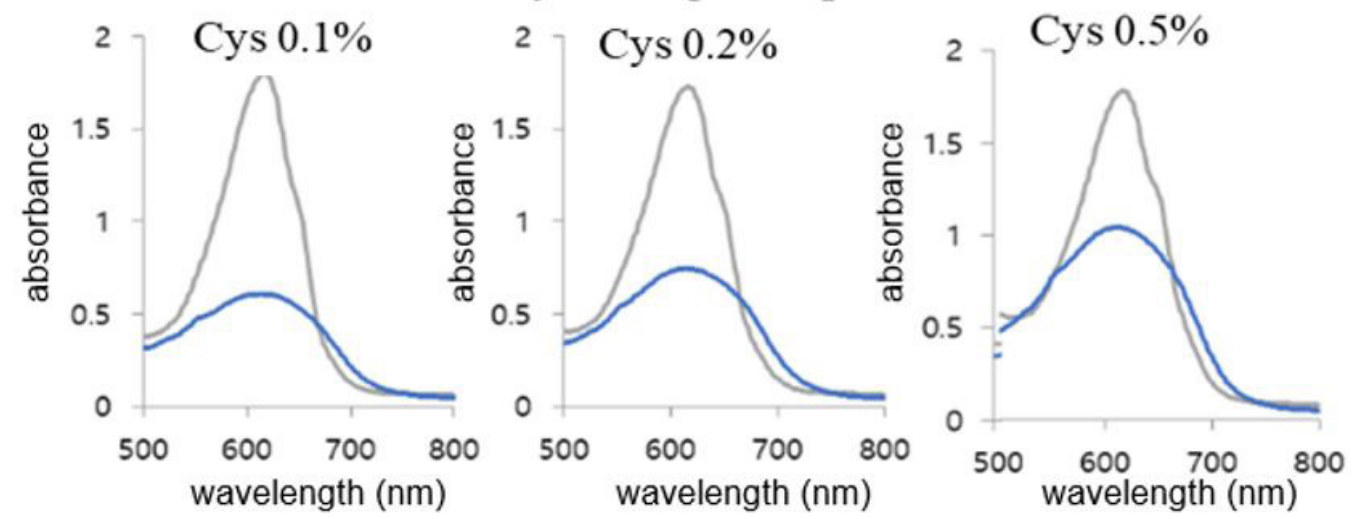

Figure 4. Changes in $\mathrm{C}_{\mathrm{R}}$ value after $95^{\circ} \mathrm{C}$ heat treatment for $10 \mathrm{~min}$ by cysteine addition during extraction with Collupulin.

Second order: $1 / C_{t}-1 / C_{0}=-k_{2} t$

where $C_{\mathrm{t}}$ is the variable content studied at time $t, C_{0}$ is the value at time zero, $k_{0}$ is the zero-order kinetic constant, $k_{1}$ is the firstorder kinetic constant, and $k_{2}$ is the second-order kinetic constant.

To determine whether the thermal degradation of phycocyanin proceeds by 0,1 , and 2 reactions, the $C_{R}$ value was measured after the phycocyanin extract obtained by extraction with Collupulin and Cys was heat-treated at 70,80 , and $90^{\circ} \mathrm{C}$ and pH 5.0 (Figure 5). In addition, the correlation index $\left(\mathrm{R}^{2}\right)$ was calculated to confirm the kinetic model of the thermal degradation of phycocyanin. Figure 5 shows that the thermal degradation of phycocyanin obtained from the extraction with Collupulin, and Cys was modeled by second-order kinetics ( $\mathrm{R}^{2}$ ranging from 0.825 to 0.960 ), which had a higher $\mathrm{R}^{2}$ value than zero-order and first-order kinetics ( $\mathrm{R}^{2}$ ranging from 0.739 to 0.850 and 0.764 to 0.907 , respectively). Therefore, the kinetic model for thermal degradation of phycocyanin extracted with Collupulin and Cys was conducted according to the second order.

To evaluate the thermal stability of phycocyanin according to the extraction method and timing of Cys addition, Ea was calculated, which required obtaining the reaction constant of the thermal degradation and a thermal degradation kinetic model, particularly the reaction constant from the model. Phycocyanin extracted with Collupulin and Cys was subjected to thermal degradation in accordance with the second-order reaction among the zero-, first-, and second-order thermal degradation reactions (Figure 5).

\subsection{Activation energy for thermal degradation of phycocyanin}

To find the minimum energy required to initiate the thermal degradation of phycocyanin, the activation energy (Ea) for thermal decomposition of phycocyanin must be determined. The reaction constant $k$ was obtained from the thermal degradation kinetic models (Figure 5), and Ea was calculated using the following Arrhenius Equations 6 and 7:

$k=C^{-E a /(R T)}$

$\ln k=-\frac{E a}{R}\left(\frac{1}{T}\right)-\ln C$

where $\mathrm{C}$ is the phycocyanin concentration, $k$ is the kinetic rate constant, Ea is the activation energy, $\mathrm{R}$ is the ideal gas constant, and $\mathrm{T}$ is the absolute temperature $(\mathrm{K})$.

Ea of phycocyanin according to the extraction method shows a difference in slope (Figure 6). During extraction with Collupulin, addition of Cys showed that Ea for thermal degradation 

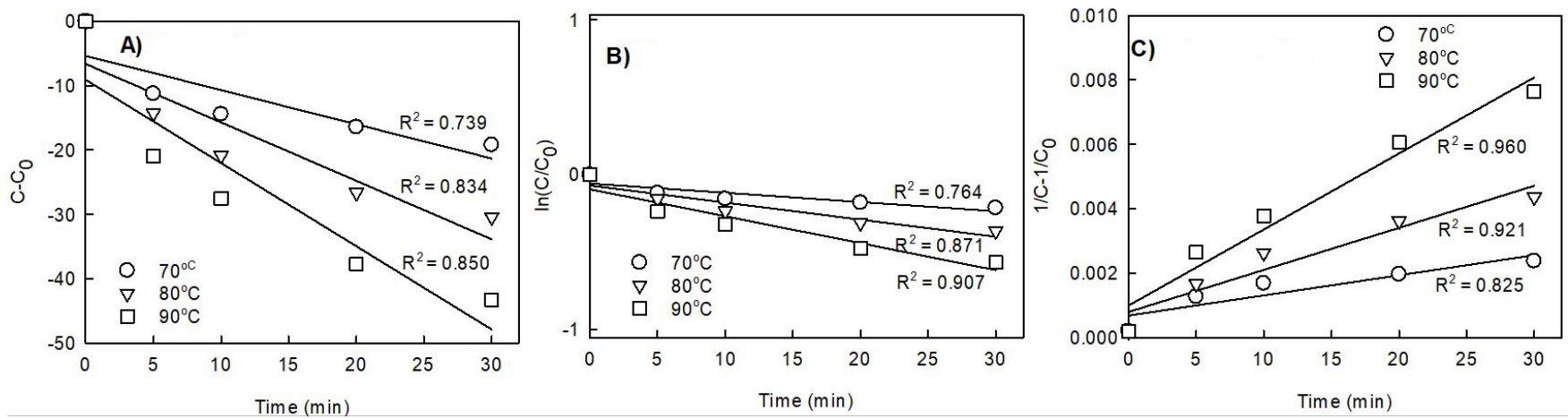

Figure 5. Zero-, first-, and second-order models for thermal degradation kinetic of phycocyanin extracted with Collupulin and Cys. (A) Zero order; (B) First order; (C) Second order.

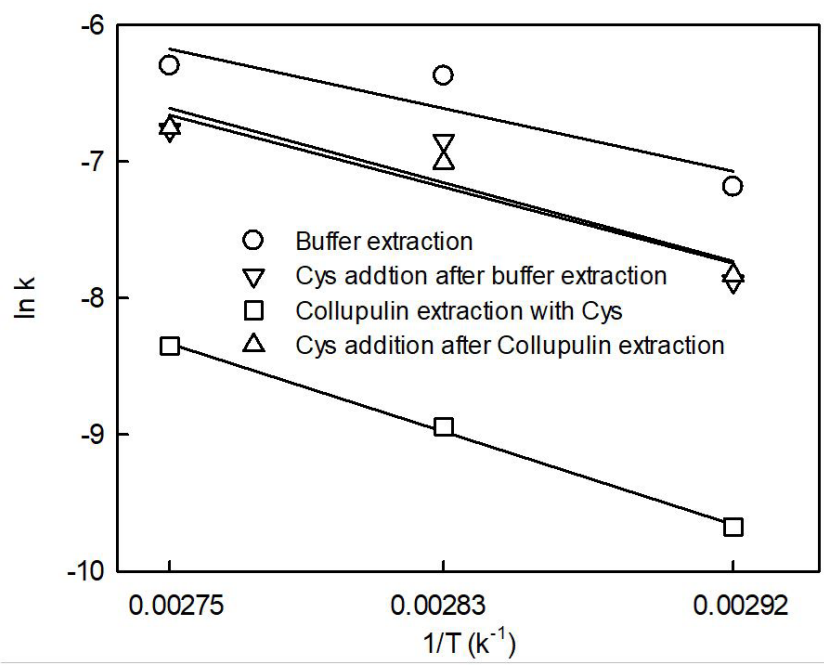

Figure 6. Arrhenius plot for determination of activation energy for phycocyanin thermal degradation using different extraction methods.

of phycocyanin was $68.64 \mathrm{~kJ}$, and that of phycocyanin obtained by extraction with citrate buffer was $53.58 \mathrm{~kJ}$. Ea for thermal degradation of Cys-added phycocyanin after extraction with Collupulin and after buffer extraction was 57.89 and $56.14 \mathrm{~kJ}$, respectively. Cys addition during extraction with Collupulin increased the Ea against thermal degradation compared to other phycocyanin extracts, confirming that it increases the thermal stability of phycocyanin.

The thermal degradation kinetic model of phycocyanin reportedly follows first-order kinetics in an aqueous solution (Hadiyanto et al., 2018; Chaiklahan et al., 2012; Antelo et al., 2008) and zero-order kinetics in powder (Colla et al., 2007). Antelo et al. (2008) reported that the kinetics of thermal degradation of phycocyanin solution depend on the first-order reaction. However, they reached a conclusion by only comparing the zero- and first-order kinetic reactions. It is reported that the kinetic model for thermal degradation when sugar is added to phycocyanin is based on first-order kinetics, not zero- or secondorder kinetics (Hadiyanto et al., 2018). However, it is also known that the thermal degradation characterization of phycocyanin using a nonlinear motion model, such as the sigmoidal curve model (Faieta et al., 2020), can better estimate the color loss during heat treatment. A recent thermal degradation study of phycocyanin reported that the thermal degradation kinetics of phycocyanin is nonlinear. The study described the discoloration process using the sigmoidal curve model (Faieta et al., 2020). Therefore, it has been reported that the thermal degradation model of phycocyanin is based on various models according to the type of phycocyanin extract, and the recent trend is reportedly based on the nonlinear model. In the present study, phycocyanin extracted with Collupulin was also measured to conform to the second-order reaction kinetics, which is a nonlinear model.

\section{Conclusions}

Phycocyanin is a natural pigment obtained from spirulina and has superior thermal stability and extraction amount when extracted with Collupulin and Cys compared to when extracted with buffer alone, citrate buffer and Cys, and adding Cys after extraction with Collupulin. Phycocyanin extracted with Collupulin and Cys was confirmed to be in accordance with the secondary pyrolysis model and have relatively high thermal stability. Phycocyanin, a highly thermally stable active ingredient extracted from Spirulina with Collupulin and Cys, offers the potential to play an important role as a new active substance in the food industry. Extraction of phycocyanin using proteolytic enzyme not only improves the yield, but also has the advantage of less destruction of active ingredients because it is extracted at low temperatures, providing economic benefits to producers. In addition, the addition of Cys improves the thermal stability of phycocyanin, showing that it is economically feasible for use in the food industry.

\section{References}

Antelo, F. S., Costa, J. A. V., \& Kalil, S. J. (2008). Thermal degradation kinetics of the phycocyanin from Spirulina platensis. Biochemical Engineering Journal, 41(1), 43-47. http://dx.doi.org/10.1016/j. bej.2008.03.012.

Arad, S. M., \& Yaron, A. (1992). Natural pigments from red microalgae for use in foods and cosmetics. Trends in Food Science \& Technology, 3, 92-97. http://dx.doi.org/10.1016/0924-2244(92)90145-M.

Bae, G. Y., Noh, D. O., \& Suh, H. J. (2020). Phycocyanin extraction from spirulina platensis using enzymes. Journal of the Korean Society of Food Science and Nutrition, 49(4), 370-376. http://dx.doi. org/10.3746/jkfn.2020.49.4.370. 
Bennett, A., \& Bogorad, L. (1973). Complementary chromatic adaptation in a filamentous blue-green-alga. The Journal of Cell Biology, 58(2), 419-435. http://dx.doi.org/10.1083/jcb.58.2.419. PMid:4199659.

Berns, D. S., \& MacColl, R. (1989). Phycocyanin in physical chemical studies. Chemical Reviews, 89(4), 807-825. http://dx.doi.org/10.1021/ cr00094a005.

Chaiklahan, R., Chirasuwan, N., \& Bunnag, B. (2012). Stability of phycocyanin extracted from Spirulina sp.: Influence of temperature, $\mathrm{pH}$ and preservatives. Process Biochemistry, 47(4), 659-664. http:// dx.doi.org/10.1016/j.procbio.2012.01.010.

Colla, L. M., Oliveira Reinehr, C., Reichert, C., \& Costa, J. A. (2007). Production of biomass and nutraceutical compounds by Spirulina platensis under different temperature and nitrogen regimes. Bioresource Technology, 98(7), 1489-1493. http://dx.doi.org/10.1016/j. biortech.2005.09.030. PMid:17070035.

Faieta, M., Neri, L., Sacchetti, G., Di Michele, A., \& Pittia, P. (2020). Role of saccharides on thermal stability of phycocyanin in aqueous solutions. Food Research International, 132, 109093. http://dx.doi. org/10.1016/j.foodres.2020.109093. PMid:32331695.

Fass, D. (2012). Disulfide bonding in protein biophysics. Annual Review of Biophysics, 41(1), 63-79. http://dx.doi.org/10.1146/annurevbiophys-050511-102321. PMid:22224600.

Fukui, K., Saito, T., Noguchi, Y., Kodera, Y., Matsushima, A., Nishimura, H., \& Inada, Y. (2004). Relationship between color development and protein conformation in the phycocyanin molecule. Dyes and Pigments, 63(1), 89-94. http://dx.doi.org/10.1016/j.dyepig.2003.12.016.

Glazer, A. N. (1985). Light harvesting by Phycobilisomes. Annual Review of Biophysics and Biophysical Chemistry, 14(1), 47-77. http:// dx.doi.org/10.1146/annurev.bb.14.060185.000403. PMid:3924069.

Hadiyanto, C., Christwardana, M., Sutanto, H., Suzery, M., Amelia, D., \& Aritonang, R. F. (2018). Kinetic study on the effects of sugar addition on the thermal degradation of phycocyanin from Spirulina sp. Food Bioscience, 22, 85-90. http://dx.doi.org/10.1016/j. fbio.2018.01.007.

Jespersen, L., Strømdahl, L. D., Olsen, K., \& Skibsted, L. H. (2005). Heat and light stability of three natural blue colorants for use in confectionery and beverages. European Food Research and Technology, 220(3-4), 261-266. http://dx.doi.org/10.1007/s00217-004-1062-7.

Kannaujiya, V. K., \& Sinha, R. P. (2015). Impacts of varying light regimes on phycobiliproteins of Nostoc sp. HKAR-2 and Nostoc sp. HKAR11 isolated from diverse habitats. Protoplasma, 252(6), 1551-1561. http://dx.doi.org/10.1007/s00709-015-0786-5. PMid:25772678.

Kay, R. A., \& Barton, L. L. (1991). Microalgae as food and supplement. Critical Reviews in Food Science and Nutrition, 30(6), 555-573. http:// dx.doi.org/10.1080/10408399109527556. PMid:1741951.

Kumar, D., Dhar, D. W., Pabbi, S., Kumar, N., \& Walia, S. (2014). Extraction and purification of C-phycocyanin from Spirulina platensis. Indian Journal of Plant Physiology, 19(2), 184-188. http:// dx.doi.org/10.1007/s40502-014-0094-7. PMid:25089058.

Lafarga, T., Fernández-Sevilla, J. M., González-López, C., \& AciénFernández, F. G. (2020). Spirulina for the food and functional food industries. Food Research International, 137, 109356. http://dx.doi. org/10.1016/j.foodres.2020.109356. PMid:33233059.

Liu, Q., Huang, Y., Zhang, R., Cai, T., \& Cai, Y. (2016). Medical application of Spirulina platensis derived C-phycocyanin. Evidence-Based Complementary and Alternative Medicine, 2016, 7803846. http:// dx.doi.org/10.1155/2016/7803846. PMid:27293463.

Mishra, S. K., Shrivastav, A., \& Mishra, S. (2008). Effect of preservatives for food grade C-PC from Spirulina platensis. Process Biochemistry, 43(4), 339-345. http://dx.doi.org/10.1016/j.procbio.2007.12.012.

Mishra, S. K., Shrivastav, A., Pancha, I., Jain, D., \& Mishra, S. (2010). Effect of preservatives for food grade C-Phycoerythrin, isolated from marine cyanobacteria Pseudanabaena sp. International Journal of Biological Macromolecules, 47(5), 597-602. http://dx.doi.org/10.1016/j. ijbiomac.2010.08.005. PMid:20709098.

Nege, A. S., Masithah, E. D., \& Khotib, J. (2020). Trends in the uses of spirulina microalga: a mini-review. Jurnal Ilmiah Perikanan dan Kelautan, 12(1), 149-166. https://doi.org/10.20473/jipk.v12i1.17506.

Palinska, K. A., \& Krumbein, W. E. (2000). Perforation patterns in the peptidoglycan wall of filamentous cyanobacteria. Journal of Phycology, 36(1), 139-145. http://dx.doi.org/10.1046/j.1529-8817.2000.99040.x.

Petersen, S. B., Jonson, V., Fojan, P., Wimmer, R., \& Pedersen, S. (2004) Sorbitol prevents the self-aggregation of unfolded lysozyme leading to an up to 13 degrees $\mathrm{C}$ stabilisation of the folded form. Journal of Biotechnology, 114(3), 269-278. http://dx.doi.org/10.1016/j. jbiotec.2004.07.004. PMid:15522436.

Sánchez, M., Bernal-Castillo, J., Rozo, C., \& Rodríguez, I. (2003). Spirulina (Arthrospira): an edible microorganism: a review. Universitas Scientiarum, 8(1), 7-24.

Santiago-Santos, M. C., Ponce-Noyola, T., Olvera-Ramírez, R., OrtegaLópez, J., \& Cañizares-Villanueva, R. O. (2004). Extraction and purification of phycocyanin from Calothrix sp. Process Biochemistry, 39(12), 2047-2052. http://dx.doi.org/10.1016/j.procbio.2003.10.007.

Sonani, R. R., Rastogi, R. P., Patel, R., \& Madamwar, D. (2016). Recent advances in production, purification and applications of phycobiliproteins. World Journal of Biological Chemistry, 7(1), 100-109. http://dx.doi.org/10.4331/wjbc.v7.i1.100. PMid:26981199.

Verdasco-Martín, C. M., Echevarrieta, L., \& Otero, C. (2019). Advantageous preparation of digested proteic extracts from Spirulina platensis biomass. Catalysts, 9(2), 145. http://dx.doi.org/10.3390/catal9020145.

Volkin, D., \& Middaugh, C. (1992). Stability of protein pharmaceuticals Part A-chemical and physical pathways of protein degradation. New York: Springer. 